\title{
The Reproductive Biology of Rock Ptarmigan (Lagopus mutus) in the Central Canadian Arctic
}

\author{
RICHARD C. COTTER ${ }^{1}$
}

(Received 3 April 1997; accepted in revised form 13 July 1998)

\begin{abstract}
This paper reports on the nesting phenology, breeding biology, and attrition rates at different stages of the breeding cycle of a population of rock ptarmigan (Lagopus mutus) at Windy Lake, Northwest Territories, from 1987 to 1989 . By early May, males were on the study area, mostly in flocks numbering in the tens and hundreds. Females arrived two to three weeks later, about one week after males had dispersed and established territories. All males succeeded in establishing a territory, but only $83 \%$ were successful in attracting a mate. There were no unmated females. All but one male were monogamous. The initiation of laying was highly synchronous both within and between years, beginning shortly after ground snow cover receded below 50\% (early June). Initiation of laying and clutch size were not correlated with either pre-incubation body weight or wing chord of females. The majority $(71 \%)$ of hens that deserted or had their first nest depredated during laying renested. However, renesting was rare once incubation had commenced. Clutch size of first nests (mean $=8.7$ ) was significantly larger than that of renests $($ mean $=5.0)$. In one year, adults laid larger clutches than yearlings; this did not result, however, in adults' fledging larger broods than yearlings that year. Pooling years, yearling females were as successful as adults: the proportion of first nests initiated that fledged was 0.56 for yearling hens and 0.55 for adult hens. Of all the hens that settled to breed at Windy Lake in 1988 and 1989, 57\% were successful in fledging a brood. Predation was the major cause of complete nest failures. Predation of clutch caused most failures (72\%), followed by depredation of the hen (24\%) and brood predation (4\%).
\end{abstract}

Key words: reproduction, population attributes, rock ptarmigan, Lagopus mutus, Northwest Territories

RÉSUMÉ. Cet article fait état de la phénologie de la nidification, de la biologie de la reproduction et des taux de réduction naturelle à différents stades du cycle reproducteur d'une population de lagopèdes des rochers (Lagopus mutus) à Windy Lake (Territoires du Nord-Ouest) de 1987 à 1989. Au début de mai, les mâles se trouvaient sur le site de l'étude, pour la plupart en volées regroupant des dizaines et des centaines d'individus. Les femelles arrivaient deux à trois semaines plus tard, environ une semaine après que les mâles se soient éparpillés et aient établi leur territoire. Tous les mâles ont réussi à établir leur territoire, mais seulement 83 p. cent ont réussi à attirer une partenaire. Il n'y a eu aucune femelle non fécondée. Tous les mâles sauf un se sont révélés monogames. Le début de la ponte s'est produit à peu près au même moment, au sein d'une même année et d'une année à l'autre, commençant peu après que la couverture de neige ait reculé de plus de $50 \mathrm{p}$. cent (début juin). Le début de la ponte et la taille des couvées n'étaient pas corrélés avec le poids corporel d'avant la couvaison ni avec la corde de l'aile des femelles. La plupart (71 p. cent) des femelles qui ont abandonné le nid, ou dont le premier nid a été pillé durant la ponte, ont effectué une ponte de remplacement. Ce phénomène était cependant rare une fois que la couvaison avait débuté. La taille des couvées des premiers nids (moyenne de 8,7) était sensiblement plus grande que celle des nids de remplacement (moyenne de 5,0). Une année, les adultes ont pondu des couvées plus importantes que les individus d'un an; cela n'a cependant pas résulté en un meilleur taux d'envol pour les couvées des adultes que pour celles des oiseaux d'un an. Toutes années confondues, le taux de réussite pour les individus d'un an était comparable à celui des adultes: la proportion des tout premiers nids qui ont produit des oiseaux qui ont pu s'envoler était de 0,56 pour les femelles d'un an et de 0,55 pour les femelles adultes. De toutes les femelles qui avaient commencé à nicher à Windy Lake en 1988 et 1989, 53 p. cent ont pu produire une couvée qui a réussi son envol. La prédation était la cause principale des échecs complets dans la nidification. La prédation de la couvée était la cause principale des échecs (72 p. cent), suivie par la déprédation de la femelle ( 24 p. cent) et la prédation des petits (4 p. cent).

Mots clés: reproduction, caractéristiques de l'ensemble de la biocénose, lagopède des rochers, Lagopus mutus, Territoires du Nord-Ouest

Traduit pour la revue Arctic par Nésida Loyer.

\footnotetext{
${ }^{1}$ Department of Zoology, University of Alberta, Edmonton, Alberta T6G 2E9, Canada; present address: 620 chemin Craig, Saint Sylvestre, Quebec G0S 3C0, Canada; rcotter@globetrotter.net

(C) The Arctic Institute of North America
} 


\section{INTRODUCTION}

The rock ptarmigan (Lagopus mutus) has one of the widest distributions of any grouse species (Johnsgard, 1983), yet has been one of the least studied. Its reproductive biology has been documented in only a few locations throughout its range, mostly from populations in Alaska (Weeden, 1962; McGowan, 1972; Weeden and Theberge, 1972), Scotland (Watson, 1965), Iceland (Gardarsson, 1971, 1988), and Svalbard (Steen and Unander, 1985). In Canada, breeding behaviour has been described (MacDonald, 1970), as have territoriality and mating tactics (Olpinski, 1986; Brodsky, 1988; Holder and Montgomerie, 1993a). These studies, however, provided little empirical data on breeding success and patterns of attrition from egg to fledged young.

To date, the most in-depth study of the reproductive biology of rock ptarmigan was conducted by Steen and Unander (1985) on Svalbard. Their study was the first to follow the fate of marked hens from the onset of the breeding season through to the end of fledging. However, despite data on many aspects of the reproductive biology, little was reported on attrition rates during the major stages of either nesting or brood rearing. Such information is necessary to understand the role of fecundity in the life history traits of a species (Martin et al., 1989). Only recently has this type of information been collected on grouse species, with only one study of ptarmigan (L. lagopus) (Martin et al., 1989).

The objectives of this study were (1) to describe the population attributes of rock ptarmigan in the central Canadian Arctic, including the timing of spring arrival on the breeding grounds, patterns of dispersion, breeding philopatry, and demography of a breeding population; and (2) to describe the reproductive biology of rock ptarmigan and examine the patterns of attrition in fecundity.

\section{STUDY AREA}

The study area, located at Windy Lake (Fig. 1), is approximately $4 \mathrm{~km}$ inland from Hope Bay on the southeastern side of Melville Sound in central Northwest Territories (approximately $68^{\circ} 5^{\prime} \mathrm{N}$ and $106^{\circ} 40^{\prime} \mathrm{W}$ ). In 1987 , the study area, located at the south end of Windy Lake, covered $3.1 \mathrm{~km}^{2}$. In $1988-89$, this area was expanded to approximately $8.5 \mathrm{~km}^{2}$ and an area of about the same size at the north end of Windy Lake was added, resulting in a combined study area of approximately $17 \mathrm{~km}^{2}$. Topographically the area consists of gently rolling tundra punctuated by small rock outcrops. The main geological features of the area are granitic intrusions and diabase dykes and sills (Fraser, 1964). The diabase formations (lines of cliffs or circular blocks of rock rising above the surrounding terrain) provide nesting ledges of potential predators, such as gyrfalcons (Falco rusticolus), peregrine falcons (F.peregrinus), golden eagles (Aquila chrysaetos),

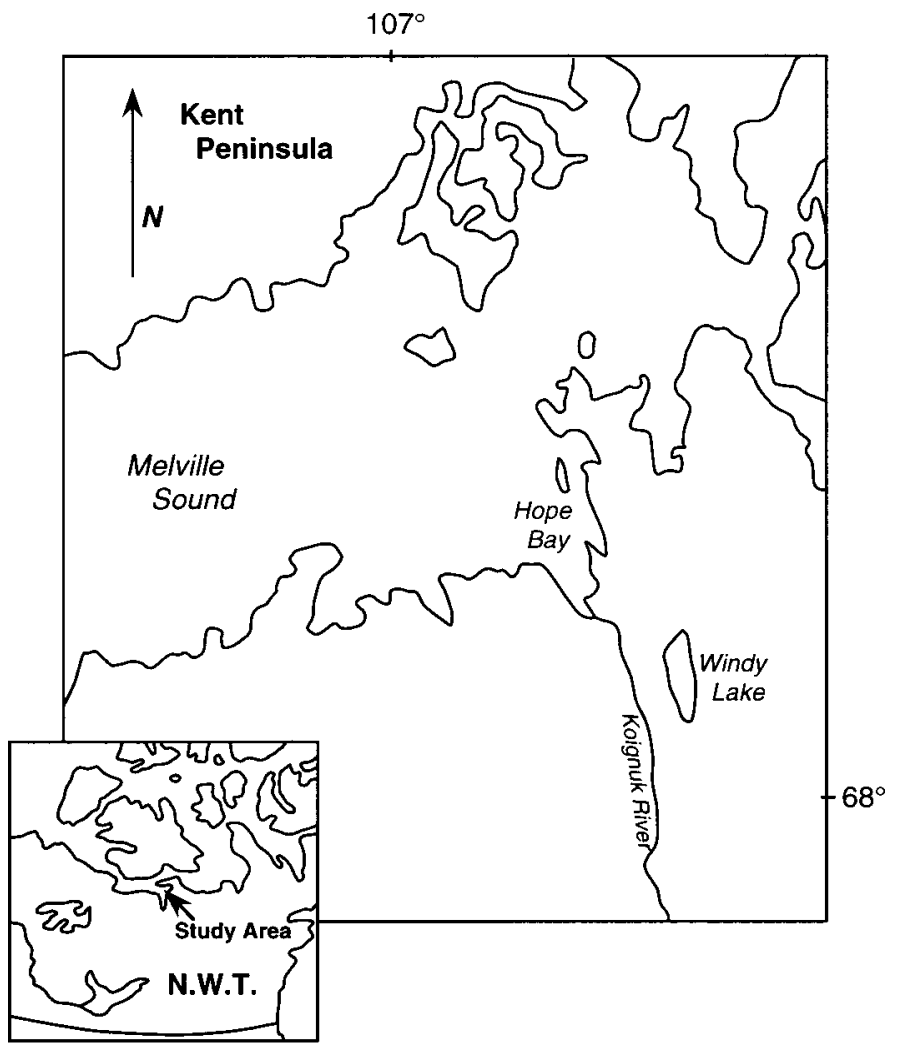

FIG. 1. Study area at Windy Lake, Northwest Territories.

rough-legged hawks (Buteo lagopus), and common ravens (Corvus corax). The flora consists of wide-ranging, lowarctic tundra species (Porsild and Cody, 1980); the dominant vascular plants being willow (Salix spp.), birch (Betula spp.), crowberry (Empetrum spp.), Labrador tea (Ledum palustre), and bell heather (Cassiope tetragona).

\section{METHODS}

All observations of rock ptarmigan at Windy Lake and its environs were recorded daily in 1987-89 from 5-9 May until commencement of nesting. Data included date, location, group size, sex, banded versus unbanded, and behaviour (such as roosting, feeding, territorial, courtship). Meteorological data and indices of spring phenology were also recorded daily, including minimum and maximum temperatures, snow cover (visual estimation), and date of flowering of herbaceous plants. Nearly all (123 of 128) of the resident rock ptarmigan at both sites on Windy Lake were captured at the onset of the breeding season (30 May-21 June) in 1987-89 using a noose pole or ground nets (Hannon, 1983). For most paired ptarmigan, the male and female were captured at the same time. For field identification, all individuals were fitted with four colourcoded leg bands: one numbered aluminum band and three numbered, coloured plastic bands. Sex, age, weight (nearest g), and wing chord length (flattened; nearest $\mathrm{mm}$ ) were recorded for all individuals. Birds were classified as either 
adult ( $\geq 1$ year old) or yearling $(<1$ year old) on the basis of pigmentation of the eighth and ninth primaries (Weeden and Watson, 1967; Parker et al., 1985). Young of the year were termed juveniles. In 1988 and 1989, all female rock ptarmigan were fitted at the time of capture with a $12 \mathrm{~g}$ "necklace" radio transmitter (Biotrack, U.K.). Only half of the males were fitted with a radio transmitter: in 1988, an 18 g "backpack" radio transmitter (Telemetry Systems, U.S.A.), and in 1989, a $12 \mathrm{~g}$ "necklace" transmitter. Transmitter type did not affect survival among males (Cotter and Gratto, 1995).

In 1988 and 1989, all captured birds that had been banded previously at Windy Lake (i.e., in either 1987 or 1988) were defined as philopatric. Birds that had not been banded previously were defined as recruits and were banded. Site fidelity, defined as the tendency of a philopatric male or female to occupy the same territory each year, was estimated by overlaying sighting locations during the territorial and nesting period of each year. The recruitment rate of rock ptarmigan to Windy Lake for breeding was calculated as the percent of resident birds attempting to breed that did not breed at Windy Lake the previous year.

The 1987 field season was exploratory in nature (i.e., to familiarize researchers with the study area and capture techniques) and did not continue past capture and banding. In 1988 and 1989, following the release of the ptarmigan, the status (territorial/non-territorial, paired/unpaired), identity of mate(s), fate (dead/alive), and territory location were determined for each bird by regular surveys (every 3 or 4 days) of their respective territories through the end of the breeding season. If an individual ptarmigan was not immediately visible, it was located by radio telemetry, or, in the case of males not radio-marked, by intensive searches of its territory. If a ptarmigan was found dead, the date, location, and condition of the carcass were recorded for later comparison with descriptions in the literature of potential predator species (Einarsen, 1956; Jenkins et al., 1964; Nielsen, 1986).

Nests were located in 1988 and 1989 by following radio-marked hens: all nests were found during laying or early in incubation. Total clutch laid (TCL) was recorded at the time of the first visit. If the nest was first found during laying, clutch size was determined during subsequent visits or at hatching by counting the number of eggs and chicks. During incubation, half the nests were visited every 3 or 4 days (disturbed), and half were not visited until hatching (undisturbed). For the latter group, the hen's approximate location and status (on or off the nest, dead or alive) was obtained every 3 or 4 days by telemetric triangulation, while remaining $50-100 \mathrm{~m}$ from the hen. This methodology enabled effects of researcher visits on breeding success (on adults, eggs, chicks) to be studied; none of the variables measured varied between disturbed and undisturbed nests or hens (Cotter and Gratto, 1995). For disturbed nests, upon each visit the hen was flushed and an egg count taken. This provided data on timing of egg or clutch loss, as well as hatching date.
If a nest was observed to have failed early in the breeding season, attempts at renesting were recorded. From these data, the probability of renesting (PRN) was calculated as the proportion of hens that renested out of the total that suffered total nesting failure (excluding the hens that were depredated).

The length of incubation in rock ptarmigan is approximately 21 days (Holder and Montgomerie, 1993b), and from nests that were visited regularly (every 3 or 4 days), it was possible to predict the date of hatching for most nests within 48 hrs. Rock ptarmigan chicks are precocial and leave the nest accompanied by the hen within $24 \mathrm{hrs}$ of hatching. All nests were checked at hatch, and when necessary 1 or 2 days post-hatch. Both clutch size at hatch $(\mathrm{CSH})$ and the number of chicks leaving the nest (CLN) were recorded. Hatching success was calculated as the number of nests that hatched at least one egg divided by the total number of nests initiated. Total nest failure (TNF) occurred if all the eggs of a nest were depredated or abandoned before hatching. At each brood visit, a brood count was taken. Broods were visited every 3 to 9 days through the end of July, by which time all were at least 16 days old. Juveniles begin to fly at 8-10 days of age (Holder and Montgomerie, 1993b), and in this study were considered to be fledged at 10 days post-hatch. Fledging success was defined as the number of chicks that fledged per brood (BSF; only hens with BSF $>0$ ) out of the number of chicks that left the nest (CLN). A successfully fledged brood was a brood in which at least one chick survived to fledging, while total brood failure (TBF) resulted when none of the chicks that left the nest survived to fledging.

Three variables describe overall reproductive performance. Reproductive success (BSF/TCL; only hens with $\mathrm{BSF}>0$ ) reflects partial loss during the breeding season, while average reproductive efficiency (RE) (BSF/TCL; all hens that laid a complete clutch) of females reflects loss during the breeding season for the whole breeding population (Martin et al., 1989). Population productivity, on the other hand, represents the average number of chicks that fledged per hen that initiated nesting.

All t-tests were two-tailed, unpaired comparisons. All $2 \times 2$ contingency analyses used the G-test of independence with Williams Correction to test for relationship between the observed frequencies for the two classes (Sokal and Rohlf, 1981). To examine if any of the variables varied over the two years or differed between the two age groups of hens, each variable was tested in a factorial analysis of variance (ANOVA), examining for year and age effects as well as for any interaction effects. Where no statistical differences were found in a category, data were pooled for subsequent analyses. Three-factor ANOVAs (year, female age, and area) produced no area effects for any of the reproductive variables (Cotter, 1991); therefore, the two areas were pooled for all analyses. To examine if clutch initiation date was correlated with pre-incubation body weight or wing chord length, Pearson correlation coefficients were calculated. Female ptarmigan accumulate 
resources for egg-laying after they arrive on the breeding grounds, so the date on which a female is captured and weighed could confound a relationship. Therefore, date of weighing was partialled out when calculating the correlation coefficient between female body weight and date of clutch initiation. The significance level was set at $\alpha<0.05$ for all tests.

Survival rates of clutches/broods from initiation of laying through to fledging, and of chicks from hatch to three weeks of age, were calculated using the KaplanMeier (K-M) product limit method, as modified by Pollock et al. (1989) for staggered entry of animals (nests or broods). Survival rates were calculated daily. A clutch/ brood whose fate was known only up to a certain date was eliminated from analysis from that date on. Survival of a clutch/brood was either 0 if total nest or brood failure occurred or 1.0 if at least one chick fledged. Statistical differences in the survival function between age groups and years were carried out using the most conservative of the three "approximate chi-square $\left(\chi^{2}\right)$ " tests presented by Pollock et al. (1989).

\section{RESULTS}

\section{Population Characteristics}

Timing of Spring Arrival: Male rock ptarmigan were observed at Windy Lake in early May in each year of this study, primarily in flocks (tens to hundreds). Most males established territories during the second week of May. Females arrived on the study area 2 to 3 weeks later than males, generally during the second and third week of May, a time when winter conditions still persisted at Windy Lake, with snow cover exceeding $80 \%$ and minimum daily temperatures below $0^{\circ} \mathrm{C}$. Prior to the arrival of the females, male rock ptarmigan concentrated their activities within large home ranges. Some territorial behaviour was displayed by the males at this time, but few aggressive boundary disputes were observed. During cold spells and storms, the males regrouped into small flocks of generally less than 20 individuals. Once the females arrived, the intensity of territorial defense and courtship displays by males increased. Although territory size was not determined in this study, it was evident from observations that territories were not contiguous. By 2 June 1988 and 4 June 1989 , less than $50 \%$ of the ground was snow-covered. These dates followed 1 or 2 warm (daily minimum temperature $>0^{\circ} \mathrm{C}$ ), calm days during which major snowmelt occurred. Laying began shortly thereafter (approximately 1 to 5 days) in both years.

Population Structure: A total of 112 rock ptarmigan were banded at Windy Lake between 1987 and 1989. The total population of resident birds was 128: 112 banded ptarmigan plus 22 recaptures plus 5 unbanded residents minus 11 banded transients. At the time of banding, the females weighed significantly more than the males, while
TABLE 1. Body weight and wing chord measurements of rock ptarmigan captured and banded at Windy Lake, Northwest Territories, 1987-89.

\begin{tabular}{llccccccc}
\hline \hline Variable & Sex & Mean & SE & $\mathrm{n}$ & Range & $\mathrm{t}$ & $\mathrm{df}$ & $p$ \\
\hline Body weight (g) & Female & 523.2 & 6.2 & 43 & $445-640$ & 3.62 & 87 & $<0.001$ \\
& Male & 498.9 & 2.9 & 46 & $470-550$ & & & \\
& Female & 182.9 & 0.8 & 47 & $172-196$ & -8.94 & 93 & $<0.001$ \\
$\begin{array}{c}\text { Wing chord } \\
\text { length (mm) }\end{array}$ & Male & 192.3 & 0.7 & 48 & $180-200$ & & & \\
\hline \hline
\end{tabular}

the wing chord of males was significantly longer than that of females (Table 1). There was no difference in body weight between adults and yearlings for either females $(\mathrm{t}=-0.69, \mathrm{df}=41, p=0.50)$ or males $(\mathrm{t}=1.56, \mathrm{df}=44$, $p=0.13$ ). Wing chord measured longer in adults of both sexes, but the difference was significant only in males (males: $\mathrm{t}=2.14, \mathrm{df}=46, p=0.04$; females: $\mathrm{t}=1.50, \mathrm{df}=$ $45, p=0.14)$. In 1987, nine males and nine females were caught and banded. In 1988, 33 males and 28 females bred or attempted to breed at Windy Lake, whereas in 1989 there were 28 males and 21 females. The ratio of adult to yearling rock ptarmigan breeding at Windy Lake varied considerably between years for both males and females. The ratio of adult to yearling males was 1:0.76 in 1988 $(\mathrm{n}=30)$ and 1:0.08 in $1989(\mathrm{n}=27)$. Among females, an opposite ratio trend was observed: 1:0.87 in $1988(\mathrm{n}=28)$, and 1:2.33 in $1989(\mathrm{n}=20)$. Pooling both years, adult males outnumbered yearling males (1:0.36), but adult females were fewer than yearling females (1:1.29). Yearlings constituted only $26.3 \%$ of territorial males but $56.3 \%$ of breeding females.

Social Mating System: Mating status was determined for all but three resident rock ptarmigan (two males in 1988; one male in 1989) at Windy Lake in 1988-89. The social mating system was predominantly monogamous; out of a total of 48 males (years pooled) that attracted a mate, only one was bigamous. Not all territorial males were successful in attaining a mate; in $1988,9.7 \%(3 / 31)$ remained unmated, whereas in $1989,25.9 \%(7 / 27)$ of the males were unmated. On the other hand, all female residents $(n=49)$ on the study area were paired in both years.

Recruitment and Annual Return Rate: More males $(75.0 \%, 15 / 20)$ than females $(11.1 \%, 2 / 18)(\mathrm{G}=16.54$, $\mathrm{df}=1, p<0.01)$ that were resident at Windy Lake at the end of the 1988 breeding season returned to Windy Lake in 1989. Combining spring records of 1988 and 1989, a total of 19 males and 3 females returned to breed a second year at Windy Lake for an annual return rate (ARR) of $48.7 \%$ for males and $8.1 \%$ for females. Adult and yearling male rock ptarmigan had similar annual return rates, $47.8 \%$ and $50.0 \%$, respectively. Although the territories were not accurately mapped, site fidelity was evident in all philopatric individuals. Of the three females that were philopatric in 1988 or 1989 , one paired with the same mate in both years. 
The analysis of birds returning to Windy Lake in more than one year is limited to birds banded in 1987. One of the nine males banded in 1987 was known to have been depredated that summer. Of the remaining eight (whose fate was not followed that summer), four $(50 \%)$ returned in 1988 , and of those, two (50\%) returned again in 1989. Of the nine females banded in 1987, none returned in both 1988 and 1989 , nor did any that may have nested elsewhere in 1988 return to Windy Lake in 1989.

The percentage of new rock ptarmigan recruited into the breeding population at Windy Lake in 1988 and 1989 was significantly higher among females $(85.7 \%, 18 / 21)$ than males $(33.3 \%, 9 / 27)(\mathrm{G}=13.75, \mathrm{df}=1, p<0.01)$. Five resident ptarmigan eluded capture and were never banded: three (all males) in 1988, and two (one male and one female) in 1989. If the three unbanded males from 1988 returned in 1989, then the percentage of new recruits among males is even lower $(22.2 \%, 6 / 27)$. Of the males recruited to the area, all but one were adults, and only two were successful in attracting a mate. Recruited females, on the other hand, comprised mostly yearlings (only three were adults). All females in 1988 and 1989 initiated nesting.

\section{Reproduction}

Clutch Initiation and Size: The first egg was laid on 7 June in 1988 and on 5 June in 1989. For first nests, the mean date of clutch initiation was 9 June in $1988(n=20$, range 7-16 June), and 10 June in 1989 ( $\mathrm{n}=14$, range 517 June). In 1988, yearling hens $(n=8)$ initiated laying on 8 June, approximately 1 day earlier than adult hens $(\mathrm{n}=$ $12)$, but in 1989 yearlings $(\mathrm{n}=11)$ initiated laying on 11 June, 4 days later than adult hens $(\mathrm{n}=3)$. These results were not significantly different, however, with respect to either year (2-factor ANOVA: $\mathrm{F}=0.08, \mathrm{df}=1,30, p=$ 0.78 ) or female age (2-factor ANOVA: $\mathrm{F}=0.90, \mathrm{df}=1,30$, $p=0.35)$, though there was a significant interaction effect $(\mathrm{F}=5.27, \mathrm{df}=1,30, p=0.03)$. Clutch initiation date was not correlated with either pre-incubation body weight $(\mathrm{r}=0.05, \mathrm{n}=23, p=0.84)$ or wing chord length $(\mathrm{r}=-0.16$, $\mathrm{n}=34, p=0.39$ ). In both years, a second clutch was laid by some females that had lost their first clutch. The mean date of clutch initiation of renests, both years combined, was 12 days later ( 21 June, $n=6$, range $15-27$ June) than the mean date for first nests ( 9 June, $\mathrm{n}=34$ ). Combining both years, $85.3 \%$ (29/34) of all hens initiated their first clutch between 7 June and 11 June. Such a high degree of synchrony in initiation was observed among both adult $(86.7 \%, \mathrm{n}=15)$ and yearling hens $(84.2 \%, \mathrm{n}=19)$ in that time period.

Of hens that settled at Windy Lake to breed in 1988 and $1989,96 \%$ (47/49) initiated nesting. The other 4\% (2/49) died after pairing but before laying, and were not replaced. Of those hens with first nests that failed, excluding depredated hens, the probability of renesting was $0.38(6 / 16)$, with no difference in the proportion of adult $(0.33,2 / 6)$ and yearling hens $(0.40,4 / 10)$ that renested $(\mathrm{G}=0.06, \mathrm{df}=1$, $p=0.81$ ). Pooling data from 1988 and 1989, the probability that a female renested was significantly greater if she lost her first clutch during laying $(0.71,5 / 7)$ rather than during incubation $(0.11,1 / 9)(\mathrm{G}=5.90, \mathrm{df}=1, p=0.02)$.

Clutch size of first nests ranged from 7 to $11 \mathrm{eggs}$ (Fig. 2) and averaged 8.7, significantly higher than that of renests $(\mathrm{t}=8.57, \mathrm{df}=42, p<0.01)$ (Table 2$)$. For first nests, adult hens laid significantly larger clutches than did yearlings in $1989(\mathrm{t}=2.30, \mathrm{df}=15, p=0.04)$, but not in 1988 $(\mathrm{t}=1.16, \mathrm{df}=19, p=0.26)$. The total clutch laid was not correlated either to body weight $(\mathrm{r}=0.21, \mathrm{n}=26, p=0.30)$ or to wing chord length $(\mathrm{r}=0.18, \mathrm{n}=37, p=0.30)$.

Hatching Success: Of all hens that initiated nesting, $63.8 \%(30 / 47)$ successfully hatched a clutch, whether from a first or a second nesting attempt. However, if the unsuccessful first nest attempts of the renesters are included, only $55.3 \%$ (26/47) had their first clutch survive to hatching, resulting in a total nesting failure (TNF) of first nests of $44.7 \%$. Eggs successfully hatched in $66.7 \%$ (26/ 39 ) of completed first nests; hens were not as successful with first clutches in $1988(54.5 \%, 12 / 22)$ as in 1989 $(82.4 \%, 14 / 17)$, though the difference was not significant $(\mathrm{G}=1.27, \mathrm{df}=1, p=0.26)$. The same success rate $(66.7 \%$, $4 / 6)$ was observed in renests. Among first nests, $17.0 \%$ $(8 / 47)$ were lost during laying, whereas $33.3 \%$ (13/39) of completed first clutches were lost during incubation: there was no significant difference $(\mathrm{G}=3.00, \mathrm{df}=1, p=0.08)$ between these periods, however. Most nest failures occurred during the first two weeks of incubation. There was no difference between adult $(55.0 \%, 11 / 20)$ and yearling $(55.6 \%, 15 / 27)$ females in the proportion of first nests that hatched and fledged $(\mathrm{G}=0.001, \mathrm{df}=1, p=0.98)$.

There was only one observed case of partial clutch loss, involving a clutch of eight eggs that had seven eggs depredated. In spite of such heavy egg predation, the hen did not abandon the nest and the one remaining egg hatched. Although direct evidence of predation was not obtained, an ermine (Mustela erminea) was observed within $20 \mathrm{~m}$ of that nest on two occasions.

Hatching failure was very low at Windy Lake: only $1.7 \%$ of eggs (4/241) failed to hatch. Thus the mean number of chicks leaving the nest (CLN) is only marginally smaller than the mean clutch size at hatch (CSH) (Table 2).

Fledging Success: Of all nests initiated, 52.8\% (28/53) were successful in fledging a brood. First nests had a higher success rate $(55.3 \%, 26 / 47)$ than renests $(33.3 \%$, $2 / 6)$, though the difference was not significant $(\mathrm{G}=0.96$, $\mathrm{df}=1, p=0.33)$. The fledging success $(\%)$ of chicks hatched from first nests $(83.3 \pm 3.7,26$ [mean \pm SE, $n])$ was also higher than that of renests $(66.1 \pm 8.9,2)$. Among first nests, year and female age did not affect either fledging success (2-factor ANOVA: year, $\mathrm{F}=0.06, \mathrm{df}=1,22, p=$ 0.80 ; female age, $\mathrm{F}=0.27, \mathrm{df}=1,22, p=0.61$ ) or brood size at fledging (2-factor ANOVA: year, $\mathrm{F}=0.79, \mathrm{df}=1$, $22, p=0.38$; female age, $\mathrm{F}=0.10, \mathrm{df}=1,22, p=0.75$ ). Although in 1989 females laid larger clutches, this did not result in larger brood sizes at fledging that year $(t=-0.87$, 


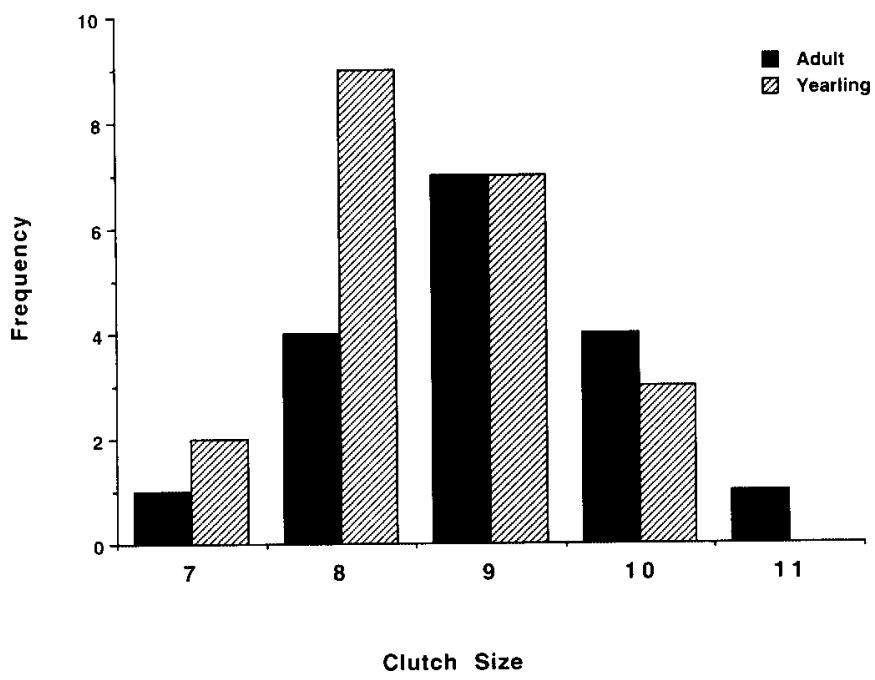

FIG. 2. Frequency of clutch sizes (TCL) of complete, first nests of adult and yearling rock ptarmigan hens at Windy Lake, Northwest Territories, in $1988-89$

df $=18, p=0.43)$. Among successful first nests, mean brood size decreased by only $5 \%$ from fledging $($ mean $=$ 7.0; Table 2) to 19 days of age $(6.6 \pm 0.5,23)$; at day 21 post-hatch, however, there was a marked decline (5.9 \pm $0.6,17)$, though sample size was much lower.

There were only two total brood failures (TBF) out of the 30 nests that hatched young, for a fledging rate of $93.3 \%$ for successful nests. One of the two TBF hens was killed when her brood was less than a week old. The other hen had a clutch of five eggs, four of which hatched, but all the chicks perished before they were 9 days old. Both of these total brood failures were from renests in 1988. There were no TBFs among first nest attempts that successfully hatched eggs.

Overall Reproductive Success: Reproductive success $(\%)$ of hens laying a first clutch $(78.8 \pm 4.5,26)$ was similar to that of hens laying a second clutch $(66.1 \pm 8.9,2)$. The mean reproductive efficiency (RE, \%), which includes failed nesting attempts, was accordingly lower for both hens laying a first clutch $(53.9 \pm 6.8,38)$ and hens that renested $(22.0 \pm 14.1,6)$. Adult and yearling females had similar $\mathrm{RE}(\mathrm{t}=-0.48, \mathrm{df}=36, p=0.63)$ among first nests, $50.3 \%( \pm 10.5,17)$ and $56.9( \pm 9.0,21)$, respectively. Combining first and renests, the mean RE was $49.6 \%$ ( \pm 6.31, 44 nests). Among completed first nests, neither year nor female age affected either reproductive success (2-factor ANOVA: year, $\mathrm{F}=0.08$, df $=1,22, p=0.79$; female age, $\mathrm{F}=0.003$, $\mathrm{df}=1,22, p=0.96$ ) or reproductive efficiency (2-factor ANOVA: year, $\mathrm{F}=1.65$, df $=1,34$, $p=0.21$; female age, $\mathrm{F}=0.09$, df $=1,34, p=0.77)$. The percentage of hens that settled at Windy Lake to breed in 1988 and 1989 that fledged a brood was 57\% (28/49), resulting in a population productivity of 3.8 chicks fledging per hen. Of 188 chicks that fledged, only 7 were from a second nesting attempt. Productivity among successful hens only was 6.7 chicks. There was no difference in the mean number of chicks produced by adult (3.8) and yearling (4.0) hens $(\mathrm{t}=-0.26, \mathrm{df}=43, p=0.80)$. The population productivity was $67 \%$ higher in 1989 (5.0 chicks per hen) than in 1988 (3.0 chicks per hen) $(\mathrm{t}=-1.92$, df $=47, p=$ 0.06). In late summer of 1988 there were 1.9 juveniles per adult; at the same time in 1989, there were 3.5 juveniles per adult. Breeding success was not related either to date of initiation of laying or to clutch size. Successful hens did not initiate a clutch earlier or later than unsuccessful hens $(\mathrm{t}=0.75, \mathrm{df}=32, p=0.46)$, nor did the hens have significantly larger or smaller clutch sizes $(\mathrm{TCL})(\mathrm{t}=0.31$, $\mathrm{df}=36, p=0.76)$.

The clutch/brood survival (K-M survival function; $\mathrm{S}[t]$ ) in 1988-89 from initiation of laying through to day 21 post-hatch, or from day 1 to day 51 , was $62.5 \%$, and $65.0 \%$ for first nests only (Fig. 3a). The rate of loss was relatively linear until day 22 post-clutch initiation, at a mean daily rate of $1.6 \%$. This date coincided roughly with the beginning

TABLE 2. Mean ${ }^{1}$ total clutch laid (TCL), clutch size at hatching (CSH), number of chicks leaving the nest (CLN), and brood size at fledging (BSF) for a population of rock ptarmigan at Windy Lake, Northwest Territories, 1988-89.

\begin{tabular}{|c|c|c|c|c|c|c|c|c|c|c|c|}
\hline Category & Variable & Mean & $\mathrm{SE}$ & $\mathrm{n}$ & Range & Category & Variable & Mean & SE & $\mathrm{n}$ & Range \\
\hline \multirow[t]{5}{*}{ First nests } & & & & & & \multicolumn{6}{|l|}{ Renests } \\
\hline & TCL & 8.7 & 0.2 & 38 & $7-11$ & & TCL & 5.0 & 0.5 & 6 & $4-7$ \\
\hline & $\mathrm{CSH}$ & 8.5 & 0.4 & 26 & $1-11$ & & $\mathrm{CSH}$ & 5.0 & 0.7 & 4 & $4-7$ \\
\hline & CLN & 8.4 & 0.4 & 26 & $1-11$ & & CLN & 4.8 & 0.8 & 4 & $4-7$ \\
\hline & $\mathrm{BSF}$ & 7.0 & 0.4 & 26 & $1-10$ & \multirow{2}{*}{\multicolumn{6}{|c|}{$1989^{2}$}} \\
\hline \multirow[t]{5}{*}{$1988^{2}$} & & & & & & & & & & & \\
\hline & TCL & 8.5 & 0.2 & 21 & $7-10$ & & TCL & 9.1 & 0.2 & 17 & $8-11$ \\
\hline & $\mathrm{CSH}$ & 7.9 & 0.7 & 12 & $1-9$ & & $\mathrm{CSH}$ & 9.0 & 0.3 & 14 & $8-11$ \\
\hline & CLN & 7.8 & 0.7 & 12 & $1-9$ & & CLN & 8.9 & 0.3 & 14 & $7-11$ \\
\hline & $\mathrm{BSF}$ & 6.6 & 0.6 & 12 & $1-9$ & & $\mathrm{BSF}$ & 7.3 & 0.6 & 14 & $1-10$ \\
\hline \multirow[t]{5}{*}{ Adult hens ${ }^{2}$} & & & & & & \multicolumn{6}{|c|}{ Yearling hens ${ }^{2}$} \\
\hline & TCL & 9.0 & 0.2 & 17 & $7-11$ & & TCL & 8.5 & 0.2 & 21 & $7-10$ \\
\hline & $\mathrm{CSH}$ & 8.2 & 0.8 & 11 & $1-11$ & & $\mathrm{CSH}$ & 8.7 & 0.2 & 15 & $7-10$ \\
\hline & CLN & 8.1 & 0.8 & 11 & $1-11$ & & CLN & 8.6 & 0.2 & 15 & $7-10$ \\
\hline & $\mathrm{BSF}$ & 6.9 & 0.7 & 11 & $1-10$ & & BSF & 7.0 & 0.5 & 15 & $1-10$ \\
\hline
\end{tabular}

${ }^{1}$ Calculation of means excluded data for failed nesting attempts (values equaling 0).

${ }^{2}$ First nests only. 


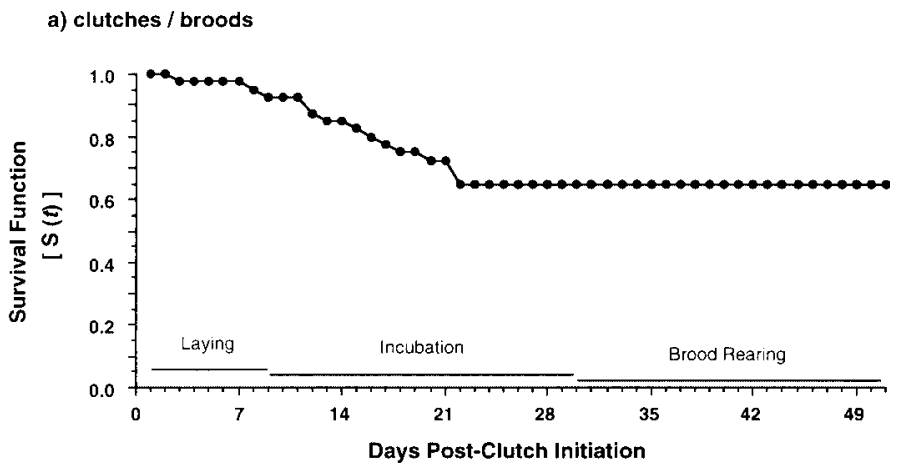

b) chicks

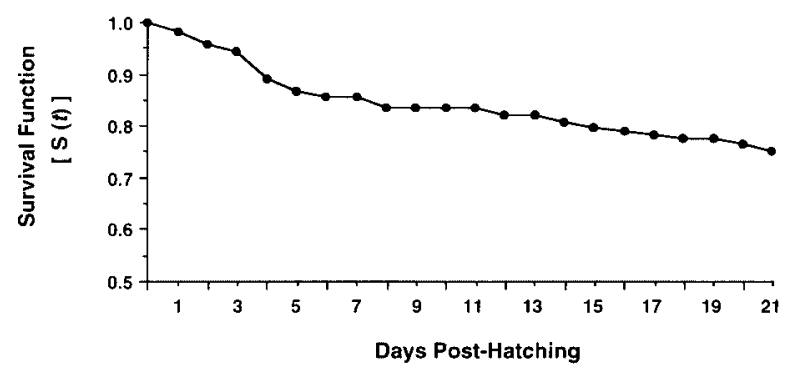

FIG. 3. The Kaplan-Meier survival function of rock ptarmigan (first nests and successful females only) at Windy Lake, Northwest Territories, in 1988-89: a) clutches and broods from clutch initiation to 3 weeks post-hatching (day 20 post-clutch initiation equals 1 July), b) chicks from hatch to day 21 post-hatch.

of week three of incubation. Survival after this date levelled off and did not decrease further, i.e., there were no further total nest failures, nor were there any total brood failures. There were no significant differences in the survival of clutches/broods (first and renests) between nests of adults $(\mathrm{S}[t]=0.62)$ and those of yearling hens $(\mathrm{S}[t]=$ 0.68) $\left(\chi^{2}=0.12, p=0.73\right)$. In 1989, however, the survival function among first nests $(\mathrm{S}[t]=0.83)$ was significantly greater than it was in $1988(\mathrm{~S}[t]=0.49)\left(\chi^{2}=4.83\right.$, $p=0.03$ ).

Among first nests there were no total brood failures; however, there was chick loss. Plotting the daily K-M survival function $(\mathrm{S}[t])$ for all chicks from hatch to 3 weeks of age shows that most chick loss occurred during the first week (Fig. 3b). The survival function at day 7 was 0.86 , declining over the next 2 weeks to only 0.75 at day 21 .

Losses-Predation: Of the females that settled at Windy Lake to breed in 1988 and 1989, eight (16.3\% of the total female breeding population, $\mathrm{n}=49$ ) died during the breeding season. Predation was the cause of all but one mortality - that of an emaciated hen found six days after banding close to where she was captured and with no visible external injuries. One hen was killed prior to laying, one during laying, four during incubation, and one during brood rearing. The observed frequencies of depredations during the stages of the breeding cycle were not statistically different from an expected equal number of depredations during each stage $\left(\chi^{2}=2.00, \mathrm{df}=1, p=0.37\right)$. As well, the proportion of hens killed before and after hatching was not different $(\mathrm{G}=3.34$, $\mathrm{df}=1, p=0.07)$.

Depredation of hens caused the failure of $11.3 \%(6 / 53)$ of all first and renesting attempts. Of all nesting failures, hen depredation was responsible for $24.0 \%$ (6/25); in 1988 depredation caused 5 of $33(15.2 \%)$ nesting attempts to fail, whereas in 1989 it caused 1 of $20(5.0 \%)$ to fail, a nonsignificant difference $(\mathrm{G}=1.30, \mathrm{df}=1, p=0.25)$. It was not ascertained what caused the other nests to fail, but the three nests that failed in 1989 were found to be empty of eggs or of any remains, suggesting predation. If predation was indeed the cause of clutch failures in both years, then nest predation accounts for $72.0 \%(18 / 25)$ of all nest failures. This contrasts with brood predation, which was responsible for only $4.0 \%(1 / 25)$ of nest failures.

\section{DISCUSSION}

In each spring from 1987 to 1989 , female rock ptarmigan arrived on the study area about 2 to 3 weeks after most males had arrived. A later arrival of females has been documented in other rock ptarmigan populations: 1 week later in northern Quebec (Olpinski, 1986), 1 to 2 weeks later on the Melville Peninsula, Northwest Territories (Brodsky, 1988), and 2 to 3 weeks later in Iceland (Gardarsson, 1988).

In both 1988 and 1989, laying began during the first week of June, shortly after 1 or 2 days of significant snowmelt when ground snow cover declined below $50 \%$. As observed in other populations of rock ptarmigan (MacDonald, 1970; Weeden and Theberge, 1972; Olpinski, 1986), initiation of laying of first nests was highly synchronous at Windy Lake, both within and between years and between adult and yearling hens. However, initiation of laying was not correlated with body weight before incubation, as Steen and Unander (1985) found in Svalbard. Steen and Unander (1985) also found that yearling rock ptarmigan hens, which weighed significantly less than adults, initiated egg-laying later than adult hens; they surmised that the later initiation by yearlings was more a function of the condition of the hen, as expressed in body mass, than of age and breeding experience. A similar relationship was observed for willow ptarmigan from northwestern British Columbia, where Hannon et al. (1988) noted that hens which laid early were significantly heavier that those that laid in middle or later periods. Observing that although hens that laid earlier were heavier, they were not larger (as measured by wing length), Hannon et al. (1988:334) concluded that "the condition of females, rather than their size, is relevant to the timing of reproduction." At Windy Lake (and also in northern Quebec; Olpinski, 1986), there was no correlation between date of clutch initiation and body weight, nor was there any difference in either the mean date of clutch initiation or body weight between the two age groups of hens. Therefore, it is 
probable that yearling hens at Windy Lake accumulate resources efficiently enough through the winter and spring to commence laying at the same time as adults.

There was no difference in the probability of renesting for adult and yearling hens. There was, however, a significantly greater probability of renesting if the first nest was lost during laying rather than during incubation. This fact is likely related to the brevity of the breeding season and the amount of investment already put into the first nesting attempt. Brodsky (1988) observed that hens that lost a clutch during laying initiated a second clutch within 1 day, but hens that lost a clutch during incubation would renest within 2 to 4 days. At Windy Lake, available data on the interval were too limited for comparisons. The mean clutch size of renests at Windy Lake was five eggs, significantly smaller than that of first nests. Smaller replacement clutches have also been recorded in rock ptarmigan from the Melville Peninsula (Brodsky, 1986) and in several populations of willow ptarmigan (Parker, 1981; Erikstad et al., 1985; Martin et al., 1989).

Male and female rock ptarmigan showed a significant difference in the proportion recruited and rate of return to the breeding population at Windy Lake. Most males in both years had previous breeding experience at Windy Lake, but very few females had any previous experience at Windy Lake. The sexes also differed in the age composition of the birds recruited. Although there were few males recruited into the breeding population in any given year, most were adults, whereas most of the females recruited were yearlings. Since there is no evidence that rock ptarmigan cannot breed in their first year (Holder and Montgomerie, 1993b), the presence of adult birds amongst recruits suggests interyear movements between breeding areas, or a failure of most yearlings to procure a territory and breed.

In many populations, there is a surplus of males that do not attract a mate, as was observed at Windy Lake. Males that were not only nonbreeding but also nonterritorial were not observed at Windy Lake. However, such groups of males, often referred to as "floaters," have been observed in Svalbard (Steen and Unander, 1985) and on the Melville Peninsula, Northwest Territories (Brodsky, 1988). At Windy Lake, some males were either never seen again or seen for only one or two days after they had been caught and banded. One such male, fitted with a radio transmitter at time of capture, remained in the same vicinity for two days, and then was never observed again (either visually or via a radio-signal). It is not known whether these transients, most of which were yearlings, were simply in transit to other breeding areas, or whether they were trying to establish a territory at Windy Lake but, after failing to do so, moved on to try elsewhere. It is possible, therefore, that adult male recruits were floaters from the previous year, or examples of breeding dispersal in males of this species.

In both 1988 and 1989, there was an excess of territorial males relative to females attempting to breed. An excess of territorial males has also been observed in populations of rock ptarmigan in Scotland (Watson, 1965), Japan (Soikiro et al., 1969), and Svalbard (Unander and Steen, 1985), but not in Iceland (Gardarsson, 1988). Rock ptarmigan in Scotland and Japan inhabit montane regions, whereas in Iceland, Svalbard, and northern Canada they inhabit arctic tundra. Gardarsson (1988) postulated that the excess of territorial males in the more southern montane regions but not in Iceland reflected a different predator community in those regions, in particular the absence of gyrfalcons. This explanation may apply as well to Svalbard, where gyrfalcons do not breed (Cramp and Simmons, 1980). However, it does not explain the excess of males at Windy Lake, as the region harbours one of the highest nesting densities of gyrfalcons in the world (Poole, 1987). Since females at Windy Lake do not suffer higher mortality than males during summer (Cotter et al., 1992), perhaps females incur higher overwinter mortality than males, which could explain both the surplus of males on the breeding grounds and the low rate of female philopatry.

It is unclear why, at Windy Lake, a few females not only were philopatric but also showed very high site fidelity between years, while other females either dispersed or suffered overwinter mortality. Possibly there were differences in prior breeding success or age of the females. The two females that were philopatric in 1989 had successfully fledged chicks in 1988. However, 11 other females at Windy Lake fledged chicks in 1988 but did not return in 1989 (fate unknown). Possibly, limited breeding dispersal among females from year to year makes the probability of finding them on the study area in subsequent years a function of the distance normally dispersed. Olpinski (1986) made such observations in northern Quebec; during the breeding season of 1984, he collected banded females on his study area that had nested there in 1982, but not in the intervening year.

The low productivity at Windy Lake in 1988 was followed by a sharp decline in the breeding population the following spring. In many populations of rock ptarmigan, as well as willow ptarmigan and red grouse (L. l. scoticus), breeding success (as measured by the number of juveniles per adult in autumn of year one) correlated positively with proportional changes in breeding numbers from year one to year two (Bergerud et al., 1985; Watson and Moss, 1987).

Most nest loss at Windy Lake occurred during the first two weeks of incubation, which coincided with the last two weeks of June. Clutch loss among first nests was linear during laying and up to the start of the third week of incubation, at which point the mean survival rate plateaued at $65 \%$ without further decrease. The major cause of total nest failure appeared to be predation. Since males do not incubate, predation of the hen necessarily resulted in the failure of the clutch. Predation of the hen was responsible for approximately one-fourth of all nests that failed during incubation. Falcons (either Falco rusticolus or $F$. peregrinus) were responsible for all but one of the 
predations, with a fox (either Alopex lagopus or Vulpes vulpes) responsible for the other (Cotter et al., 1992). Nests that suffered total clutch loss were likely depredated; data were available only for 1989, and during that summer all failed nests were found empty within three days of being depredated, with no egg shell remains or other sign of the predator. Both avian and mammalian nest predators often remove eggs from nests of grouse and waterfowl, leaving no trace of their identity (Myrberget, 1985; Trevor, 1989). In many populations, foxes and ermines are major egg predators (Weeden and Theberge, 1972; Steen and Unander, 1985; Brodsky, 1988) and they, along with ravens and gulls (Larus spp.), are the most likely predators involved at Windy Lake as well. At Windy Lake, clutch predation accounted for almost three-quarters of all nest failures.

Predation rates can be affected by populations of alternative prey for predators. Microtines at Windy Lake undergo regular population fluctuations in an approximate 3 -year cycle: they peaked in 1987, crashed in 1988, and recovered in 1989 (Cotter, 1991). Nest losses were considerably higher in the microtine "crash" year than in the following year, when microtine numbers had begun to recover. When microtine numbers crash, their predators must switch to alternative prey, such as ptarmigan clutches. Such a scenario may have occurred at Windy Lake. In his Kilgavik study area, which encompasses Windy Lake, Poole (1987) showed the significance of the timing of emergence and abundance of juvenile arctic ground squirrels (Spermophilus parryii). In June, ptarmigan made up the bulk (> $90 \%$ biomass) of the gyrfalcons' diet, whereas in July their portion dropped considerably ( $70 \%$ biomass), as juvenile ground squirrels became an important part of the diet.

\section{CONCLUSIONS}

Rock ptarmigan at Windy Lake are primarily monogamous, with males highly philopatric. Few females returned in subsequent years, suggesting low philopatric tendencies or differential (higher) overwinter adult mortality. All males established territories, though not all were successful in attracting a mate. Adult males were not more likely to return to breed a second season, nor were they more likely to attract a mate than yearlings.

Hens at Windy Lake were highly synchronous in initiation of laying, both between and within each year of the study. Laying began shortly after ground snow cover receded below 50\%, which in 1988 and 1989 occurred during the first week of June. The majority of hens that deserted or had their first clutch depredated during the laying stage renested. Hens that lost their first nest after incubation had commenced rarely renested. The majority of nest losses occurred during incubation; consequently, the probability of renesting for all hens was low, and the contribution of renests to overall fecundity was minor.
Adult hens were not more successful than yearlings in either year of the study; nor did they fledge larger broods, even though in one year they laid significantly larger clutches. Neither initiation of laying nor clutch size was correlated with preincubation body weight or wing chord length of hens.

Of all hens that settled to breed at Windy Lake in 1988 and $1989,57 \%$ were successful in fledging a brood (one or more chicks). The major cause of nest failure was predation. Clutch predation was responsible for almost threequarters of nest failures; hen predation, approximately one-fourth; and total brood loss, less than $5 \%$.

\section{ACKNOWLEDGEMENTS}

I would like to thank Jay VanderGaast, Jimmy Ayalik, John Nanuak, Doug Stern, Lisa Chalmers, Norm MacLean, and Chris Shank for their assistance with data collection. Sincere thanks to James Hare and Lorne LeClair for assistance with statistical analysis and to Cindy Gratto for reviewing this manuscript. This study was funded by a Natural Sciences and Engineering Research Council of Canada (NSERC) Post-graduate Scholarship and a Northern Science Training Grant (Canadian Circumpolar Institute). Logistical and financial support were also provided by an NSERC operating grant to David Boag and by the Department of Renewable Resources, Government of the Northwest Territories.

\section{REFERENCES}

BERGERUD, A.T., MOSSOP, D.H., and MYRBERGET, S. 1985. A critique of the mechanics of annual changes in ptarmigan numbers. Canadian Journal of Zoology 63:2240-2248.

BRODSKY, L.M. 1986. Correlates and consequences of the mating tactics of male rock ptarmigan (Lagopus mutus). Unpublished Ph.D. dissertation, Queen's University, Kingston, Ontario.

- 1988. Mating tactics of male rock ptarmigan (Lagopus mutus): A conditional mating strategy. Animal Behaviour 36:335-342.

COTTER, R.C. 1991. Population attributes and reproductive biology of rock ptarmigan (Lagopus mutus) in the central Canadian Arctic. Unpublished M.Sc. thesis, University of Alberta, Edmonton, Alberta.

COTTER, R.C., and GRATTO, C.J. 1995. Effects of nest and brood visits and radio transmitters on rock ptarmigan. Journal of Wildlife Management 59:93-98.

COTTER, R.C., BOAG, D.A., and SHANK, C.C. 1992. Raptor predation on rock ptarmigan (Lagopus mutus) in the central Canadian Arctic. Journal of Raptor Research 26:146-151.

CRAMP, S., and SIMMONS, K.E.L., eds. 1980. Handbook of the birds of Europe, the Middle East and North Africa. The birds of the Western Palearctic, Vol. 2: Hawks-Bustards. Oxford: Oxford University Press.

EINARSEN, A.S. 1956. Determination of some predator species by field signs. Oregon State Monographs 10:1-34. 
ERIKSTAD, K.E., PEDERSEN, H.C., and STEEN, J.B. 1985. Clutch size and egg size variation in willow grouse Lagopus $l$. lagopus. Ornis Scandinavica 16:88-94.

FRASER, J.A. 1964. Geological notes on northeastern District of Mackenzie, Northwest Territories. Paper 63-40. Map 451963. Ottawa: Geological Survey of Canada.

GARDARSSON, A. 1971. Food ecology and spacing behaviour of rock ptarmigan (Lagopus mutus) in Iceland. Unpublished Ph.D. thesis, University of California, Berkeley, California.

. 1988. Cyclic population changes and some related events in rock ptarmigan in Iceland. In: Bergerud, A.T., and Gratson, M.W., eds. Adaptive strategies and population ecology of northern grouse. Vol. 1. Population studies. Minneapolis, Minnesota: University of Minnesota Press. 300-329.

HANNON, S.J. 1983. Spacing and breeding density of willow ptarmigan in response to an experimental alteration of sex ratio. Journal of Animal Ecology 52:807-820.

HANNON, S.J., MARTIN, K., and SCHIECK, J.O. 1988. Timing of reproduction in two populations of willow ptarmigan in northern Canada. Auk 105:330-338.

HOLDER, K., and MONTGOMERIE, R. 1993a. Context and consequences of comb displays by male rock ptarmigan. Animal Behaviour 45:457-470.

. 1993b. Rock ptarmigan. In: Poole, A., and Gill, F., eds. The birds of North America, No. 51. Philadelphia: The Academy of Natural Sciences and Washington, D.C.: American Ornithologists' Union.

JENKINS, D., WATSON, A., and MILLER, G.R. 1964. Predation and red grouse populations. Journal of Applied Ecology 1:183195.

JOHNSGARD, P.A. 1983. Grouse of the World. Lincoln, Nebraska: University of Nebraska Press.

MacDONALD, S.D. 1970. The breeding behavior of the rock ptarmigan. Living Bird 9:195-238.

MARTIN, K., HANNON, S.J., and ROCKWELL, R.F. 1989. Fecundity of willow ptarmigan: Clutch size variation and predictability of predation. Ecology 70:1788-1799.

McGOWAN, J.D. 1972. Population characteristics of rock ptarmigan. Final report. Juneau, Alaska: Federal Aid in Wildlife Restoration.

MYRBERGET, S. 1985. Egg predation in an island population of willow grouse (Lagopus lagopus). Fauna Norvegica. Series C, Cinclus 8:82-87.

NIELSEN, O.K. 1986. Population ecology of the gyrfalcon in Iceland with comparative notes on the merlin and raven. Unpublished Ph.D. thesis, Cornell University, Ithaca, New York.
OLPINSKI, S.C. 1986. Breeding ecology, habitat and morphometrics of rock ptarmigan (Lagopus mutus) in NouveauQuebec. Unpublished M.Sc. thesis, McGill University, Montreal, Quebec.

PARKER, H. 1981. Renesting biology of Norwegian willow ptarmigan. Journal of Wildlife Management 45:858-864.

PARKER, H., OTTENSEN, H., and KNUDSEN, E. 1985. Age determination in Svalbard ptarmigan (Lagopus mutus hyperboreus). Polar Research 3:125-126.

POLLOCK, K.H., WINTERSTEIN, S.R., BUNCK, C.M., and CURTIS, P.D. 1989. Survival analysis in telemetry studies: The staggered entry design. Journal of Wildlife Management 53:715.

POOLE, K.G. 1987. Aspects of the ecology, food habits and foraging characteristics of gyrfalcons in the central Canadian Arctic. Unpublished M.Sc. thesis, University of Alberta, Edmonton, Alberta.

PORSILD, A.E., and CODY, W.J. 1980. Vascular plants of continental Northwest Territories, Canada. Ottawa: National Museum of Natural Sciences.

SOIKIRO, T., NOBUO, S., and CHIBA, S. 1969. On territory of Japanese ptarmigan (Lagopus mutus japonicus Clark) in the Murudo area, Tateyama, Japan Alps in 1967 and 1968. Miscellaneous Reports of the National Park for Nature Study $1: 14-18$.

SOKAL, R.R., and ROHLF, F.J. 1981. Biometry. San Francisco, California: W.H. Freeman and Co.

STEEN, J.B., and UNANDER, S. 1985. Breeding biology of the Svalbard rock ptarmigan (Lagopus mutus hyperboreus). Ornis Scandinavica 16:191-197.

TREVOR, J.T. 1989. Aspects of mammalian predation on upland nesting waterfowl in central North Dakota. Unpublished M.Sc. thesis, University of North Dakota, Grand Forks, North Dakota.

UNANDER, S., and STEEN, J.B. 1985. Behaviour and social structure in Svalbard rock ptarmigan (Lagopus mutus hyperboreus). Ornis Scandinavica 16:198-204.

WATSON, A. 1965. A population study of ptarmigan (Lagopus mutus) in Scotland. Journal of Animal Ecology 34:135-172.

WATSON, A., and MOSS, R. 1987. The mechanics of annual changes in ptarmigan numbers: A reply to Bergerud, Mossop and Myrberget. Canadian Journal of Zoology 65:1043-1047.

WEEDEN, R.B. 1962. Mortality and recruitment in a rising ptarmigan population. Alaska Science Conference, Juneau, Alaska, August 1962.

WEEDEN, R.B., and THEBERGE, J.B. 1972. The dynamics of a fluctuating population of rock ptarmigan in Alaska. Proceedings of the International Ornithological Congress 15:90-106.

WEEDEN, R.B., and WATSON, A. 1967. Determining the age of rock ptarmigan in Alaska and Scotland. Journal of Wildlife Management 31:825-826. 